\title{
The new Logic of Ramon Llull
}

\author{
Charles Lohr
}

ABSTRACT (The new Logic of Ramon Llull)

This paper proposes a reassesment of Ramon Llull's thought in the history of philosophy. A previous reconsideration of the history of medieval thought is required. The author refuses a finalist interpretation of the Christian thought that reduces the «rationalist» slant of Anselm and the Victorines to a philosophical moment overpassed, even buried, by Thomist criticisms. Therefore, he recognizes in the Anselmian stream a philosophical tradition of its own, historically transcending the Middle Ages and becoming one of the principal sources of Renaissance metaphysics. By reeenacting and transforming the terms of that current, R. Llull became one of its most decisive components.

\section{Ramon Llull and the History of Christian Philosophy}

In our histories of medieval thought we have concentrated on the history of Christian philosophy during the centuries which separated Augustine from Luther. Because Christian philosophy was meant to provide the praeambula to the acceptance of revelation, we have attended primarily to the history of metaphysics, ethics, and rational psychology. We have focused, above all, on the philosophical developments in Paris and Oxford which were so closely related to the evolution of Scholastic theology. As a result, we have failed to recognize some of the greatest achievements of medieval science -achievements in mathematics and natural philosophy, in the theory of the state and in the theory of what science itself is. Our paradigm has forced us to regard what is known as Averroism as an aberration and the fourteenth century as the end of a journey. We have no organic place in our histories for figures like the Englishman Roger Bacon, the Italian Pietro d'Abano, and the Catalan Arnau de Vilanova and even for such significant personalities as Dante Alighieri and Nicolaus Cusanus. In this essay I would like to outline the philosophical contribution of an author who has suffered much from the narrow scope of our current account: the Majorcan Ramon Llull.

Around the beginning of the twelfth century in the territories bordering on Islam - in Catalonia and in the kingdoms of Toledo and Sicily - there appeared a conception of knowledge and reality which opened a new period in the history of thought. The commerce and tsade which flourished in the 
Mediterranean basin formed its material basis, the spirit which animated it was a rare spirit of openness and tolerance which was born of the contact between the three great civilisations of Islam, Judaism and Christianity.

In Toledo Christians and Jews labored together to make available to the Latin West the Greek philosophy and science which had been transmitted in Arabic. Frederick II of Sicily corresponded with Moslem philosophers in the search for solutions to problems arising out of the confrontation between pagan science and the Christian tradition. In the territory of Barcelona and on the Catalan coast of southern France Jewish scholars expelled from Moslem Spain by the intolerance of the Almohade monarchs translated Arabic works into Hebrew, Hebrew and Arabic works into Latin, and even Latin works into Hebrew.

One of the most remarkable figures in this interchange was that of the Majorcan Ramon LIull. The island of Majorca was not only a centre of commercial intercourse in the Mediterranean world, but also a point where Islam, Judaism and Christianity met. Even after the Reconquista, Moslems made up a good part of the population of the island. Llull was born in 1232, some years after James the Conqueror retook Majorca from the Saracens. He died in 1316 on a ship which was bringing him home from his last voyage to North Africa, after he had - according to the local tradition- been stoned almost to death while preaching the Christian faith.

This vir phantasticus - who clothed himself as a pilgrim and probably spoke Arabic better than Latin-, sought tirelessly in Europe, North Africa and the Near East to win over the powerful of his time to the cause of understanding and concord between peoples. Conscious of the fact that he stood at the frontier between the three great religions, he sought - as an arabicus christianus- to use methods proper to the Arabic tradition to convince Moslems and Jews of the truth of Christianity.

In the pursuit of this goal, Llull's life became one of incredible literary production. In spite of his preaching, teaching and restless travel, Liull wrote some 280 works, many of them very extensive. In accordance with his purpose, these works were composed not only in Latin, but a also in Catalan and Arabic. Although the ideas in them show a rapid development, his goal remained always the same. Hc wanted to write a book which would make Christian doctrines intelligible to Moslems and Jews. He called his book the Ars inveniendi veritatem, the Art of Finding the Truth, and, regarding it as a task imposed by God himself, worked unflaggingly on the composition of this Art for more than thirty years.

His energy was not limited, however, to composing works directly concemed with his Art. He wrote in Latir on philosophy and theology, on logic and natural science, and composed in Catalan a great many popular, didactic works in all sorts of literary forms. As procurator infidelium he directed petitions to popes and cardinals and sketched in several tracts a plan for the crusade.

In his efforts to bring Moslems, Jews and Christians together, Llull was not only active as an author. He also struggled for the establishment of a new type 
of educational institution, different from the Latin universities of Paris and Oxford, in which a true dialogue between the three great mediterranean civilisations might be possible. In repeated petitions to popes and kings he pleaded for the foundation of colleges in which men prepared to die for their faith might learn the languages and doctrine necessary for preaching to Saracens and Jews.

Although he was and remained a layman, Llutl decided to dedicate his life to a missionary apostolate. To this end he planned at first to go to Paris to leam Latin and scholastic theology. He was advised, however, by Ramon de Penyafort -the same superior of the Dominican Order whose inspiration stood behind the Contra gentiles of Thomas Aquinas - to return to his native Majorca, where he could leam not only Latin but also Arabic and something of Moslem thought.

Llull not only mastered the Arabic language, but also conceived the idea of a new science which would serve high missionary purpose. This new science was based on both Latin and Arabic models. But because it was addressed to peoples of all faiths, it was not to be specifically theological, but rather a general science which could be applied to all the particular sciences of the time. Llull changed, therefore, the name of his Ars inveniendi veritatem to Ars generalis and submitted the work to constant revision throughout his long life.

\section{Ramon Llull: Arabicus Christianus}

Toward the end of the eleventh century the increasing contacts between the three great Mediterranean civilizations gave birth in the Latin West to a fundamentalky new conception of knowledge and nature. This new conception took different forms in different places and in different thinkers, but it was characterized, above all, by its dynamic understanding of reality. Impressed by the superiority of Islamic science, Western thinkers made an enomous effort not only to appropriate the results of Greek and Arabic learning, but also to develop a standpoint which would enable the Latins to appear as an equal partner in philosophical and theological discussion. This standpoint they found in the view that all reality tended actively toward the infinite. The id quo maius cogitari nequit of Anselm of Canterbury is but one aspect of this new vision. Fundamentally, the Platonism of the twelfth-century school of Chartres, the understanding of the artes mechanicae as aiming at the transformation of reality, the thirteenth-century science of optics, the linguistic and mathematical analysis of questions of continuity and the infinite, the fourteenth-century notion of the latitudo formarum. Albertist epistemology, the questioning of the geocentric hypothesis, and the new conceptions of science itself which appeared during the fifteenth century are all aspects of the same vision - aspects which have been consistently ignored in our histories of Christian philosophy.

Behind the general science which Llull thought of as applicable to all the sciences there lay the fundamental vision of a natural theology which should approach the true God through a method of contemplation. on the divine names. 
Llull called these names «dignities" or "axioms» and listed in the final form of the art nine of them: goodness, greatness, eternity; power, wisdom, love; virtue, truth and glory.

His idea seems to have been based on an Islamic method of contemplation which attempted to ascend by way of created reflections of the divine perfections to the infinite perfection which is God himself. He thought that through contemplation on combinations of these names, which are common to all religions, agreement could be reached between Moslems and Jews, Greek and Latin Christians.

One recognises the Neoplatonic axiom, Bonum est diffusivum sui, behind "goodness" as the first of the dignities. The second group of three divine names was possibly suggested by the Latin triad of potestas, sapientia, benignitas, common in the twelfth century. The inclusion of «greatness» among the principles shows very clearly however that Llull has gone beyond the static categories of ancient Neoplatonism and made Anselm of Canterbury's id quo maius cogitari nequit his point of departure.

Llull's inspiration for the way in which these names are to be understood seems at the same time to have been influenced by Islamic mystical writers. $\mathrm{He}$ composed a Liber de centum nominibus Dei in which he tells us that the Moslems believe that God has placed even more power in his names than in animals, plants and precious stones. His method of contemplation can therefore only be understood correctly if we take the dignities to stand for active powers. $\mathrm{He}$ insisted that we must refer all the powers which they designate to the supreme power of God, who created ali things.

Accordingly, Llull developed his method of contemplation not only by spelling out - horizontally, so to speak - nine different names of God, but also by making explicit - vertically - three degrees of the powers of the names.

He conceived his Art as a means of ascent which proceeds by way of two stages, a transcending of sense-knowledge by an ascent from the positive to the comparative degree of the dignities (bonum-melius) and a transcending of rational knowledge by an ascent from the comparative to the superlative degree (melius-optimum).

Liull argued that sense perception cannot form a valid basis for science; it remains on the lowest, positive level of knowledge. Reason can, however, rise to the comparative level in that it attains rational knowledge of these sensible objects. Aristotle and Avernoes attained this level. But this level is still not the level of true science. If the objects of the sense world are good and great, the objects of the rational world are better and greater. But God is with respect to all creatures the best and greatest -optimum et maximum. Only through a second ascent, therefore, can the intellect attain the level of eternal truth.

On this superlative level the differences we had encountered on the first two levels disappear. Because God is the best in the superlative degree, it is no longer possible to distinguish him as such from the greatest or the most powerful. At the superlative degree of reality the mystic discovers the supreme being in whom all the divine names coincide or fall together. 


\section{Ramon Llull: Philosophe de l'action}

Two Latin mottoes characterize two divergent approaches to the medieval problem of the relationship between faith and science. Anselm's device, fides quaerens intellectum carried the day in the twelfth century. Thinkers like Hugo of St. Victor and Alain de Lille sought rationes necessariae for the doctrines of the faith. But at the beginning of the thirteenth century a new device appeared on the field, the motto, fides non habet meritum cui humana ratio praebet experimentum, of Pope Gregory IX. Anselm's idea — which has been seriously misinterpreted by the historians of Christian philosophy - was formulated in the context of the dialogue between the three great mediterranean religions. The new papal device represented a narrowing of the European vision. It was this device that implied the separation of theology from philosophy. Philosophy was assigned the task of providing reasons for the acceptance of a body of doctrinem not for the doctrines themselves. The history of this approach is well known. It is the history of the Christian philosophy which we have written. Anselm's approach did not however remain submerged. It surfaced again in different guises in the early fourteenth century.

In his works Llull sought above all to render intelligible the Christian doctrine on which all missionary intent had foundered, the doctrine of the Trinity. For this purpose he had recourse to an analysis of what it means when we say that the powers of the divine names are active. He held that we cannot truly call something good which does not produce a good.

In this way Llull introduced a completely new category in the history of metaphysics. In accordance with his apologetic purpose he spoke not only of principles of being, but also of principles of action. He proposed the thesis not only that God is productive contingenter and ad extra in creation, but also that the divine persons are productive necessarie and ad intra.

Taking his point of departure from the dynamism which his Islamic partners in dialogue admitted, the dynamism of the process of knowledge (the knowing intellect, the known object, and the act of knowledge) and love (the lover, the beloved, and love itself), Llull maintained that we must admit the activity of all the divine perfections. True goodness must produce something good; true greatness must produce sornething great.

Because action presupposes a principle or source, that which is produced, and a bond between them, he spoke not only of the dignities, but also of their acts and the «correlatives» of their action. To designate these correlatives, he formed new words which appear strange in Latin and were probably formed on the analogy of the forms of the Arabic verb. In a sermon given in Tunis he explain:

Actus... bonitatis dico bonificativum, bonificabile, bonificare; actus etiam magnitudinis sunt magnificativum, magnificabile, magnificare; et sic de aliis omnibus divinis dignitatibus.

Llull generalised this idea to the extent that he could speak even of the abstract moments of activity as tivum, bile and -are. He defined these 
moments as substantial and intrinsic principles of action which are valid for all reality. In this way he was able to recognise images of the triune God in all aspects of the created world, in the form, matter and conjunction which make up corporeal things; in the form, subject and property which constitute the nature of the angels; and even in the three dimensions of bodies and the two premisses and one conclusion of the syllogism. Above all in the union. Syllogism - above all in the union of knower and person known in the act of mystical knowledge and in the union of a lover and a beloved bound together in the active love. $\mathrm{A}$ lover and a beloved bound together in true active love.

Llull was aided in his apologetic purpose by the analysis of the knowledge of the illuminated mystic current among some Moslem thinkers. Certain Christian controversialists writing in Arabic had taken up as an analogy for the Trinity Aristotle's description of God as vonors vonoews, as it had been expanded in Neoplatonism from two to three terms. Some Mostem writers accepted this idea for the mystical knowledge of God in which the knower, the object known and the act of knowing itself are one.

Llull was able to join this analogy with Augustine's famous comparison of the Trinity with human love. In his De amic e amat, a charming little book which is one of the great glories of the Catalan language, Llull maintained that true, active love presupposes a lover, the beloved, and the love itself which unites them.

Because the correlative principles are intrinsic to all activity, action and passion are not, as in Aristotle, accidental. For Llull, being and activity both belong to the substance of things and are identical.

Because activity implies relatedness, Llull added, in the later forms of the Art, nine relative dignities to the absolute ones listed earlier: difference, contrariety, concordance; greaterness, lesserness, equality; beginning, middle and end; "contrariety", "greaterness» and «lesserness" are encountered in the created world, but on the superlative level of the divine activity there remain only «difference», «equality» and «concordance».

The infinitely great, divine optimans can only produce the divine optimatum which is its «equal»; the "difference» between them being necessarily transcended in the "concordance» of the divine optimare, while all three together form the «beginning», «middle» and «end» of all things.

In the sermon quoted above Llull made clear the relationship of his dynamic understanding of reatity to the chartrain triad of unitas, aequalitas and connexio. He concluded:

Per praedictarum... dignitatur... substantiales actus intrinsecos et aeternos, acqualiter et concordanter acceptos... probant evidenter Christiani in una simplicissima divina essentia ct natura esse trinitatem personarum, scilicet Patris et Filii et Spiritus sancti.

Thus for Llull the correlative unfolding of all things became an absolute ontological principle. Even the divine unity known through faith must be structured. As an active unity it must have a moment which is to be united. If God is truly one in an active sense of the word, he must be triune, even though 
on the superlative level of the divine activity the manner in which God is triune eludes man's understanding.

Having thus discovered the Christian Trinity in the mediated unity of the most simple divine essence, Llull also sought, by means of the dynamic dignities of his Art, to make intelligible the doctrine, known to Christians by faith, of the incarnation of Christ. To this purpose he appealed to the distinction between the necessary activity of the dignities ad intra, and their contingent activity ad extra. Whereas the divine activity ad intra is necessary, the creation of the world ad extra is dependent on the divine will. But when God has freely chosen the creation of the world, the infinite first cause can only achieve concord with its effect:

In Filii Dei incarnatione, per participationem scilicet unionis creatoris et creaturae in una persona Christi.

Aristotle's theory of science, which begins with self-evident principles in order to present a body of doctrine deductively, was well suited to the thirteenth-century idea of the relation between faith and reason. The articles of faith could be taken as the first principles for a Summa of theology. The Anselmian approach implied a different theory of science - a theory of a science which ascends beyond all hypotheses and principles to the one presuppositionless beginning of all knowledge and all reality. The opposition between two approaches should not be understood simply as an opposition between Aristotelianism and Platonism. Thirteenth-century Aristotelians were able to fit many Neoplatonic ideas into their syntheses since they were easily adaptable to the idea of the theologians that Adam's fall darkened man's intellect and weakened his will. The often proclaimed great thirteenth-century synthesis between Platonism and Aristotelianism was in fact the result of the desire to show not only that revelation is in accord with reason, but also that it is necessary, since man's nature is a fallen nature. The approach of Anselm of Canterbury represented rather something completely new in the history of philosophy. In accordance with his idea, some fourteenth-century thinkers saw creation and man's place in it more optimistically. Their views implied the abandonment of the hierarchical division of nature into supra- and sub-lunary realms and saw the earth not as the lowest of a series of nccessary emanations, but as a noble star, differing only in brilliance from the other stars of the heavens .

Applying his ideas to the creation of the world, Llull strongly emphasized not only the dynamic character of God's causal action, but also that of its effect, the created world itself. He applied the distinction between necessary activity ad intra and contingent activity ad extra to the activity of creatures. To explain how the distinction applies to creaturely activity, he employed the example of a property in a subject.

Fire, for example, must necessarily burn, but whether it heats water or bums wood is contingent. Within itself fire is active «substantially» and «in a proper way"; in water or earth it is active "accidentally» and "in an 
appropriated way». The form of whiteness is active within itself, but when it contingently whitens (albificat) this or that body, it is present in the body in a «contracted» way.

For Llull therefore creation is a likeness of God because of its dynamic character. Not only does God's activity of creation not ccase with the bestowal of being on the world, but the world which God has treated is itself active, tending to its own perfection.

Just as whiteness can seek to increment its contract perfection in an appropiated way, by whitening more and more individual bodies, so also the creator has so created the various species that they tend to increase their perfection by numerical multiplication.

Although the particular, individual things of which the world is made up are in process tending toward perfection, no individual thing can atain the full perfection of its species. The species is the limit to which the perfection of the individual approaches, the genus that of the species, the universe that of the genera.

Llull understood the individuals, species and genera which we encounter in the world as parts of a whole, as components of a unity reflecting the dynamic greatness of the creator. He presented his understanding of this whole - this universe- most clearly in his epoch-making Liber chaos, a work which he appended to the second redaction of his Art, the Ars demonstrativa.

In this work Llull broke with the medieval idea of a Stufenkosmos. He gives no account of the heavenly spheres and their angelic movers, but focused his attention rather on the sublunary world of the four elements. His book understands chaos neither as a primordial void in the sense of disorder and confusion nor as materia informis in the sense of the Augustinian theology of creation.

For Llull chaos is rather the complex of all the things which were created by God in a unique act, together with all the determinations categorizing them. Chaos contains the semina causalia whith are the grounds for all things, the forma universalia and the materia universalis, the genera and species, the substantiae and accidentia. From chaos proceeds everything which is beneath the sphere of the moon. In the semina causalia of chaos alt the individual transmutationes, all the various possibilities of individual development, are already present. The transmutations of chaos do not affect its essence. They are rather various actualizations of that which is already present in chaos in potentia.

In his conception of chaos Liull thus brought together a great many different ideas from the philosophical tradition. He divided chaos into three degrees. In the first degree we find the rationes seminales of the Stoics in the role of a genus for both the Platonic notion of a world soul and the Aristotelian predicables and categories. In the second degree we find the first individuals of the particular species, in the third all the individuals deriving from these first ones.

But LIull's use of these ideas completely transformed their meaning. The Platonic idea of an anima mundi is associated with the Aristotelian doctrine of 
matter and form, but understood in terms of the Llullian correlatives of action. Chaos is made up of the four abstract essences of the four elements: igneitas, aeritas aqueitas, terreitas. Each essence has its proper correlatives, its proper form (ignificativum), its proper matter (ignificabile) and its proper act (ignificare).

The matter and form of the various individuals in chaos should not be thought of as limited to the individuals All the proper forms are pined together in a unique forma universalis -a corpus mundi -which is the total sum of all the possible (-bilia). Taken together, this universal form and this universal matter make up the unum esse, the unum suppositum, which Llull calls chaos.

From the universal form and universal matter emerge the genera and species, substances and accidents, and from them in turn the individual things composed of particular forms and matters. Each particular form and each particular matter is grounded in the universal form and matter. In accordance with his doctrine of relative principles Llull understood the second degree of chaos as mediating between the original semina causalia and the final perfection which the individuals find in their numerical multiplication.

But the concrete individual things which emerge from the semina causalia tend not only to their extrinsic, numerical multiplication. They tend also to their intrinsic, proper perfection. By nature each concrete thing strives to fulfill the abstract essence from which it has emerged. It was in this sense that Lluil maintained that the categories and predicables and the union of universal form and universal matter are real things. The abstract is already really present in individual things as the limit of theirs striving toward infinity.

In his Liber de natura, a treatise which is intimately connected with the final redaction of Art, Llull defined nature as the principle through which the entia concreta - the individual man (homo), for example - approach ever more closely the entia abstracta - the essence of man (humanitas).

For this reason Llull could adopt the Neoplatonic idea of nature as the vis animae universalis which is the third emanation from the One. In the Ars generalis ultima he described nature as the essentia in suo naturali concreto sustentata et mota per actum naturalem. Accordingly, he thought of the essences of things as vires, as powers which are moved by the natures in them. At each degree of their return to the original unity the respective -tiva form the natura naturans, the respective -bilia the natura naturata, and the respective -are the union of both.

In this way chaos taken as a whole can be understood as the reflection of the divine nature whose dynamism unfolds in a threefold natura, a natura naturans, a natura naturata and a natura naturare.

\section{From Anseim's Maximum to the Dignitas hominis of the Renaissance}

The two divergent conceptions of knowledge and reality which ran in parallel currents through the entire medieval period came into open conflict over the nature of man. The conflict reached its high point in the debates concerning 
the nature of Christ and the necessity of the Incarnation. The course the conflict took has been obscured by the fact that Scholasticism distinguished Christian philosophy from theology and regarded christological questions as belonging exclusively to a supernatural theology. But the medieval christological debates did not concern simply the question of the nature of Christ. At a more profound level, they were at so discussions about the nature of man himself -about the maximum of which he is capable. Because the proponents of the distinction between Christian philosophy and theology wanted to underline the necessity of revelation consequent upon Adam's fall, they regarded the Incarnation of Christ as only contingently necessary, that is, as necessary only to repair the damage done to man's nature through original sin. But outside strictly Scholastic circles -and even in some circles generally thought to belong to Scholasticismmany thinkers maintained the absolute necessity of the Incarnation, sceing Christ as the culmination of creation and the absolute perfection to which human nature necessarily tends. The history of medieval philosophy can not ignore such attempts to conceive of man as the dynamic bond which strives to join spiritual and material reality. These attempts were made in accordance with an understanding of human knowledge and a conception of nature which was different from that of the proponents of the notion of a Christian philosophy, but they enable us to appreciate the continuity which exists between Anselm's idea of the maximum and the Renaissance conception of the dignitas hominis.

Llull's distinction between necessary activity ad intra and contingent activity ad extra was also crucial for his idea of man. In accordance with his conception of the mediate place of the incarnate Christ between the first cause and its effect, he defined man by way of his relationship both to God and to the world.

With respect to creation, Llull held that man is a "microcosm». Although he was referring to the traditional motif which saw man as a world in miniature, he modified the traditional understanding of this idea radically. Man is a microcosm, not because he comprises in himself all the different degrees of reality and thus is subject to all its antagonistic forces, but rather because he forms the center of creation, uniting in himself the lowest level of intellectual reality and the highest reach of sensible being and is thus a bond which holds creation together.

With respect to the creator, man is himself creative ad extra, bringing forth ideas, instruments, tools and works of art. In producing tools and works of art, man uses materials he finds in nature, but the forms he gives them are not mere imitations of natural things. They are true productions of his own mind. Man's creative power thus approaches that of God. But whereas God brings forth as real beings the things that he understands, man's mind is not able to produce real beings, it can only represent them and appropriate them to itself.

The metaphysical distinction between necessary and contingent activity was fundamental for LIull's understanding of man, above all because it enabled him to analyze more profoundly the nature of human knowledge. He had maintained that things like fire and whiteness have their own necessary, intrinsic and proper correlatives of action, whereas their obiects ad extra (earth or water, this or that body) are contingent, extrinsic and appropriated to them. 
In the very important late work De potentia, obiecto et actu Llull drew the consequences of this idea for human knowledge. The sensible things which the mind encounters in the world are not necessary objects of knowledge. Even the instruments and tools which the mind itself produces are objects appropriated by the mind to itself. The proper object of the mind must be an interior reality. Just as the proper object of fire is not earth or water, but rather fire itself as ignitable, so asso the proper object of the mind can only be the mind itself as knowable.

To discover its true self, the mind must withdraw from the otherness and contingency which is involved in sense perception and rational knowledge. The mind must tum inward. It must tum away from its contingent activity ad extra and ascend to its own necessary, intrinsic dynamism.

The condition of the mind's return to itself is a deliberate, prior choice. Man's ultimate autonomy is grounded not only in his faculties of knowledge, but also in his ability freely to choose. Through his faculties of knowledge man can comprehend all things; through his freedom he can become all things. He has the ability to choose to belong to himself, to free himself from the world and realize all the interior potentialities of his nature.

In thus reflecting on himself, man becomes a proper object of knowledge for himself. Since the knowledge of an object presupposes a disposition in the object enabling it to be known, man thus discovers himself as knowable. To explain that necessary process of human knowledge ad intra, Llull turned to his theory of the correlatives of action: the knower (intelligens) knows himself as knowable object (intelligibile) in the activity of knowing (intelligere). This triadic structure does not imply a spitting up of man into three separate entities. Man knows himself as knowable, but relates this knowable object to himself.

A.t the same time, man becomes conscious of his own finitude. His knowledge is limited not only because it has to have recourse to sensible images. In order to understand the things which the mind discovers in the world -things which are in constant process, tending to their own perfection- it must reduce them to the static categories of discursive reason. Even its knowledge of those things brought forth by its own creativity is restricted because its ideas can only be realized in an alien matter.

Above all, however, it is in his effort to discover himself that man is, --confronted with the limitations of his nature. Although he must free himself from exterior things to find himself, the nature of his mind compels him to go out to exterior things before he can begin to return inwardly to himself.

From this vantage-point it is easy to appreciate the originality of Liull's Logica nova, a work which belongs to the period of the Ars generalis ultima. The logic of this work is new because it is meant to be a logic of pure knowing, a logic whose first intention is to consider the intellectual things which are the proper object of the intellect. It is only in a second intention that the new logic must consider the appropriated objects of the intellect, the ideas which the intellect abstracts from sensible things.

Reflecting Llull's idea of an intellectual ascent, the second figure of the Ars generalis ultima distinguishes three degrees of knowledge: sensible knowledge 
of sensible things, intellectual knowledge of sensible things, and intellectual knowledge of intellectual things. Since the Logica nova was conceived as a logic for the third degree of knowledge, the intellectual knowledge of intellectual things, it is at the same time a critique of the traditional logic and the theory of knowledge on which it was based. For Llull, Aristotle's logic was deficient because it limited itself to the intellectual knowledge of sensible things.

It is true that in the twelfth century certain thinkers recognized the possibility of a logic for the intellectual knowledge of intellectual things. Following Boethius, they distinguished between «intelligibilia», that is, the objects of the second degree of knowledge, and «intellectibilia», those of the third degree. But the thirteenth-century reception of Aristotle focused attention on the formulation of a logic of the second degree of knowledge, the intellectual knowledge of sensibic things, and precluded an attempt to analyze the conditions of its possibility.

This is the reason why Llull's prologue to the Logica nova speaks of the unstable character of the traditional logic and proposes to reconstruct it on a new foundation, that of the third degree of knowledge. Because it concerns intellectual knowledge of intellectual things, Llull spoke of this highest degree of knowledge as a «natural» manner of knowing. Making use of his distinction between the necessary and the contingent correlatives of action, he regarded intellectual things as the necessary, intrinsic, proper objects of knowledge and criticized the traditional logic as one which treats only "peregrine» knowledge; the knowledge of contingent, extrinsic, appropriated objects, the sensible things encountered in this world.

Man's true nature is spiritual and tumed to intellectible things. But he must go out to corporeal reality and appropriate to himself sensible things in order to be able to return to his proper self. Corporeal things - the subjects of the Art, imaginativa, sensitiva, vegetativa, elementativa - are all only instruments for man's realization of reason in the world. This is the reason why the Logica nova situates man on the border-line between spiritual and corporeal reality.

Man's proper function - as homificans animal in the enigmatic definition of the Logica nova - is the hominization of the animal, vegetable, and elemental kingdoms, and through them of the whole univers. Man is man not only because he seeks to approach ever more closely his abstract essence as animal rationale, but also because he seeks the complete transformation of his genus. The individual strives upward to the species, the species to the genus, and the genus to the original cosmic unity which is made up of universal form and universal matter.

Man is a microcosm, a bond joining spiritual and corporeal reality, because the tivum of his rational nature is able to appropriate to itself the various subjects which make up the universe. But the condition of the possibility of this appropriated knowledge lies in the proper, third degree of knowledge for which the Logica nova is meant.

In his reflection on himself, man thus achieves a new modesty, a modesty which gives birth to the realization that there must exist-beyond his own 
contracted -bile an absolute -tivum which is not only the origin and source, but also the end and perfection of all things. There is no comparison possible between the divine-tivum and the human -bile. But because God himself is the condition of the encounter between himself and man his transcendence is not infringed upon by being taken up in the process of human knowledge. The triadic structure of the necessary, intrinsic mode of understanding permits union without identification.

God is knowable, not as are the exterior things which are the contingent objects of human knowledge. He is the complementary part of the process of knowledge which takes place in the meeting of two subjects, each of whom experiences himself as knower and known, while both are united in the activity of knowing. Because God is bimself intellect -intelligens intelligibile, intelligere- the created intellect can attain union with him and beatitude.

The condition of this union is that man be in complete possession of himself. He must freely respond to God's knowability. Through his free choice of himself, man is able, to transcend sense impressions and rational concepts and attain the superlative One in whom all perfections fall together.

Man realizes himself, all the interior potentialities of his nature, in this union. The triadic structure of his knowledge makes him an image of God. In his encounter with the exemplar - a transcendent exemplar which is the beginning, middle, and end of his striving - man arrives at the dynamic repose which is the activity of knowing. The measure of his own truth is the degree of intensity with which he reflects the divine exemplar. The gulf which separates exemplar and image, God and man, could only be bridged if God himself assumed human nature and elevated it to a maximum perfection.

Llull's conception of Christ as the God-man gives us the key to his understanding of the created world. In the incarsate Christ his conception of the universe reaches its culmination. The full perfection of the universe demands the union of creator and creature. This does not imply that Christ is a mediate nature between divinity and humanity, but rather that in his person the divine nature and the created nature of the universe are brought together.

Christ is the bond joining God and the world, because as an individual he is the fulfillment of all the interior potentialities of the species and through him the human species is the fulfillment of the universe. In his human nature he is the supreme limit of the active striving of all nature to its perfection and in his divine nature he is the perfect image of the Father. 